\title{
Peningkatan Strategi Pembelajaran Seni Musik untuk Meningkatkan Prestasi Belajar Pada Siswa Kelas IX.10 di SMP Negeri 13 Pekanbaru
}

\author{
Marjeni Maisasna * \\ * SMP Negeri 13 Pekanbaru
}

\begin{tabular}{l}
\hline INFO ARTIKEL \\
\hline Riwayat Artikel: \\
Diterima: 6 Maret 2018 \\
Disetujui: 10 Juni 2018
\end{tabular}

Kata kunci:
Strategi Pembelajaran
Seni Musik
Prestasi Belajar

\section{Alamat Korespondensi:}

Marjeni Maisasna, SMP Negeri 13 Pekanbaru

Jl. Ronggowarsito I No. 15 Pekanbaru

E-mail: marjeni.maisasna@gmail.com

\begin{abstract}
ABSTRAK
Abstract: Based on the results of the research that has been obtained about the strategy of learning music art to improve student achievement in SMP Negeri 13 Pekanabaru, some conclusions can be drawn such as the following: Learning preparation strategies. The main step shown by the teacher with the preparation of lesson plans that is oriented towards the curriculum and syllabus used. The RPP lists the strategies and methods of learning that are applied. Management strategies in each class. Teachers teach with different methods for each class because each class has different characters. Strategy for using learning media. The teacher leads to preparation and utilizing media and learning tools that are in accordance with the material and facilities available in the school's music lab. Strategy approach to motivate students. To motivate students, the teacher takes a personal, group and functional approach. The strategy of motivational approaches by teachers is supported by school participation by providing a means of supporting good learning. Strategy for evaluation and value taking. In this strategy the teacher holds a score not only in the UTS and UAS, but by holding a daily test after the completion of Basic Competence. The teacher also conducts assessments at any time in the learning process takes place by looking at the students' responses, seeing the answers to oral questions from the teacher. The results of the evaluation will be followed up by the teacher as the stage of learning learning. Strategies for developing students' musical art learning experiences. In this strategy the teacher develops student learning activities, by increasing the learning activities of music practice compared to learning music theory, but by not putting aside the theory that remains present throughout the course of learning. In addition, there are also many activities or activities supporting the achievement of students' musical arts achievements at school
\end{abstract}

\section{LATAR BELAKANG}

Dalam upaya peningkatan kualitas pendidikan, Standar Proses Pendidikan/SPP memiliki peranan penting, dalam hal ini guru merupakan komponen yang sangat penting, sebab keberhasilan pelaksanaan proses pendidikan sangat tergantung pada guru sebagai ujung tombak. Oleh karena itulah upaya peningkatan kualitas pendidikan seharusnya dimulai dari pembenahan kemampuan guru. Salah satu kemampuan yang dimiliki guru adalah bagaimana merancang suatu strategi pembelajaran yang sesuai dengan tujuan atau kompetensi yang akan dicapai, karena kita yakin tidak semua tujuan bisa dicapai oleh hanya satu strategi tertentu. 
Penggunaan strategi dalam kegiatan pembelajaran sangat perlu karena mempermudah proses pembelajaran sehingga dapat mencapai hasil yang optimal. Tanpa strategi yang jelas, proses pembelajaran tidak akan terarah sehingga tujuan pembelajaran yang telah diterapkan sulit tercapai secara optimal, dengan kata lain pembelajaran tidak dapat berlangsung secara efektif dan efisien. Strategi pembelajaran sangat berguna, baik bagi guru maupun siswa. Bagi guru, strategi dapat dijadikan pedoman dan acuan bertindak yang sistematis dalam pelaksanaan pembelajaran. Bagi siswa, pengguna strategi pembelajaran dapat memepermudah proses belajar, mempermudah dan mempercepat memahami isi pembelajaran, karena setiap strategi pembelajaran dirancang untuk mempermudah proses belajar siswa.

Kurikulum Tingkat Satuan Pendidikan (KTSP) memuat tentang Standar Kompetensi (SK) dan Kompetensi Dasar (KD) pendidikan seni, budaya, dan keterampilan menjelaskan bahwa pendidikan seni musik sifat multilingual, multidimensional, dan multikultural. Mata pelajaran seni budaya telah menjadi mata pelajaran wajib di sekolah, akan tetapi, dalam pelaksanaannya pembelajaran seni musik ini masih banyak kendalanya. Hal ini disebabkan oleh karena kurangnya apresiasi terhadap pembelajaran musik. Menumbuhkan apresiasi siswa terhadap pembelajaran musik sangat diperlukan upaya dari guru musik itu sendiri.

Pendidikan seni musik di tingkat pendidikan dasar dan menengah ditengarai mengalami keterpinggiran seperti halnya pada pendidikan musik berintegrasi dengan bidang seni lainnya yakni pendidikan tari, pendidikandrama, dan pendidikan seni rupa. Pendidikan seni musik seringkali tidak diberikan secara professional, masih banyak terdapat sekolah sering kali tidak diampu oleh pendidikan seni musik, melainkan oleh guru yang berlatarbelakang pendidikan lain atau oleh guru kelas. Selain itu, pendidikan seni musik diperparah dengan terjadinya distorsi dan reduksi didalam memaknai pendidikan seni musik. Pendidikan seni musik diberikan dengan penekanan pada aspek teoritis-kognitif atau aspek pengetahuan, dengan mengabaikan praktik dan pengalaman bermusik. Pendidikan musik tidak dilengkapi dengan sarana dan prasarana yang memadai.

Pendidikan seni musik bukanlah sekedar hiburan untuk memancing siswa menjadi semangat dalam belajar, seperti yang didengungkan sebagian guru selama ini. Ketika siswa merasa bosan dengan salah satu mata pelajaran, maka dinyanyikanlah sebuah lagu. Pendidikan seni musik pada hakekatnya memiliki peranan yang sangat penting dalam membentuk manusia seutuhnya. Melalui pembelajaran yang terarah seni musik dapat dijadikan sebagai alat media guna membantu mencerdaskan kehidupan, mengembangkan manusia yang berbudaya yang memiliki keseimbangan otak kanan dan kirinya ,keseimbangan akal, pikiran, dan kalbunya dan memiliki kepribadian yang matang. Untuk mencapai tujuan pendidikan seni, siswa perlu dibekali pengetahuan, pengalaman, dan berbagai kemampuan, serta pemahaman wawasan sebagai pengembang budaya bangsa. Atas dasar itulah diupayakan pelajaran melalui kegiatan praktek, khususnya dengan mendengarkan dan memperdengarkann (Jamalus, 1991: 6).

Pendidikan seni musik di sekolah seyogyanya diberikan perhatian mendalam, perhatian tersebut dimaksudkan untuk menumbuhkan minat dan apresiasi siswa terhadap seni musik. Belajar musik merupakan pembelajaran yang kompleks, karena melibatkan aspek apresiasi, kepekaan rasa, ketrampilan motorik, kreativitas (Rachmad dan Milyartini, 2004: 42). Unsurunsur dalam musik yaitu unsur panjang-pendek (durasi), tinggi-rendah (pitch), keras-lembut (dinamik), cepat-lambat (tempo) dan warna suara (timbre) merupakan kesatuan yang tidak dapat dipisahkan, karena menyatu dalam wujud musik (Rachmad dan Milyartini, 2004: 43). Prestasi musik, kemampuan musikal maupun keterampilan dalam melaksanakan pertunjukan musik merupakan sebagian kemampuan musikal yang menjadi sasaran evaluasi dalam pendidikan musik (Rachmad dan Milyartini, 2004: 42). Sasaran evaluasi kurikulum berbasis kompetensi untuk mata pelajaran senitermasuk musik tercantum dalam kurikulum 2004 sebagai berikut: "Pembelajaran mata pelajaran kesenian menekankan pada pengembangan kepekaanestetik yang diimplementasikan dalam ketiga kompetensi dasar pendidikan seni yangmeliputi konsepsi, apresiasi dan kreasi.”

Ruang lingkup isi pembelajaran seni musik mencangkup apresiasi karya seni musik dan mengekspresikan diri melalui karya seni musik. Oleh karena itu wawasan umum yang luas tentang musik dan bagaimana mengembangkan materi ajar musik, akan membantu guru dalam melaksanakan pencapaian kompetensi dasar 
seni musik. Untuk cakupan apresiasi guru perlu memahami bagaimana mengembangkan kegiatan apresiasi siswa, antara lain membahas musik, jenisnya, serta hal hal yang menyangkut analisa keindahan dan keunikan musik. Tahapan apresiasi juga diperlukan untuk membimbing siswa melakukan kegiatan apresiasi. Apresiasi siswa terhadap mata pelajaran seni musik dapat ditumbuh kembangkan dengan strategi guru yang tepat. Berbagai hal yang dapat meningkatkan apresiasi perlu disadari guru sehingga dapat menciptakan pembelajaran yang membuat siswa apresiatif terhadap mata pelajaran seni musik.

Guru seni budaya yang kompeten yaitu yang menguasai merencanakan dan melaksanakan strategi pembelajaran seni budaya. Penguasaan strategi pembelajaran mencakup: strategi pengorganisasian, strategi penyampaian, dan strategi pengelolaan pengajaran. Strategi penyampaian pengajaran merupakan salah satu bagian penting keterampilan yang perlu dikuasai guru seni budaya. Strategi penyampaian pengajaran berkaitan dengan keterampilan guru dalam menerapkan langkah-langkah menyajikan pembelajaran, meliputi keterampilan: menyajikan materi pembelajaran, menerapkan pendekatan atau metode pembelajaran, menggunakan media pembelajaran, dan menggunakan asesmen sesuai perencanaan pengajaran.

Sekolah ini telah berhasil melaksanakan pembelajaran seni musik. Strategi pembelajaran seni musik di SMP ini menjadi menarik untuk diteliti. Berdasarkan latar belakang masalah tersebut melakukan penelitian tentang strategi pembelajaran seni musik untuk peningkatkan prestasi belajar siswa di SMP Negeri 13 Pekanbaru.

\section{METODE}

Penelitian ini bertujuan untuk mengetahui strategi pembelajaran seni musik untuk meningkatkat prestasi belajar seni musik siswa di SMP Negeri 13 Pekanbaru. Data yang digunakan dalam penelitian ini adalah data kualitatif. Menurut Moleong (2006:44), penelitian kualitatif berlatar belakang alamiah sebagai keutuhan, mengandalkan manusia sebagai alat penelitian, berpikir secara induktif, dan bersifat deskriptif. Penelitian deskriptif merupakan penelitian mengenai keadaan gejala menurut apa adanya pada saat penelitian dilakukan. Data yang dikumpulkan adalah berupa kata-kata, gambar, dan bukan angka-angka (Moleong, 2006:11).

Sumber data mengenai Strategi pembelajaran seni musik untuk meningkatkan strategi pembelajaran seni musik siswa ini diperoleh dari hasil pengamatan dalam pelaksanaan pembelajaran di dalam kelas, ketersediaan alat musik di SMP Negeri 13 Pekanbaru, persiapan guru dalam mengajar sampai pada strategi penyampaian pembelajaran seni musik. Sumber data pertama adalah wawancara dengan guru musik SMP Negeri 13 Pekanbaru yang bernama Marjeni Maisasna S.Pd, mengenai persiapan guru mengajar, strategi yang dilakukan, dan sarana prasarana yang ada di sekolah serta untuk digunakan dalam pembelajaran seni musik. Sumber data yang kedua adalah dokumentasi yang berasal dari kurikulum, silabus, RPP, materi pembelajaran, dan observasi kelas pada saat guru mengajar.

Teknik pengumpulan data dalam penelitian ini secara berurutan menurut keutamaan dan skala prioritasnya adalah sebagai berikut: wawancara, observasi, dan dokumentasi. Dalam penelitian kualitatif, peneliti sendiri atau dengan bantuan orang lain merupakan alat pengumpul data utama (Moleong, 2006: 09). Instrumen utama dalam penelitian ini adalah peneliti sendiri. Dalam mengumpulkan data, peneliti dalam penelitian ini menggunakan panduan observasi langsung dan panduan wawancara. Informan yang dibutuhkan dalam penelitian ini yaitu informan yang dapat dipercaya dalam perolehan informasi dan data mengenai permasalahan yang diteliti. Informan dalam penelitian ini yaitu guru seni musik, kepala sekolah dan siswa siswi SMP Negeri 13 Pekanbaru. Data dalam penelitian ini dianalisis dengan model analisis interaktif. Menurut Miles dan Huberman (1992:16-19) model ini terdiri dari tiga komponen, yaitu reduksi data, penyajian data dan penarikan kesimpulan yang dilakukan dalam bentuk interaktif, pengumpulan data sebagai siklus. Ketiga komponen tersebut dapat dijabarkan sebagai berikut: 1) reduksi data, 2) Penyajian Data, dan 3) Penarikan kesimpulan. 
70 Instructional Development Journal (IDJ), Vol. 1, No. 2, Desember 2018, Hal. 67-80

\section{HASIL DAN PEMBAHASAN}

Pelaksanaan pembelajaran memerlukan strategi yang tepat untuk mencapai tujuan pembelajaran. Penggunaan strategi dalam kegiatanpembelajaran dimaksudkan untuk mempermudah proses pembelajaran sehingga dapat mencapai hasil yang optimal. Keberhasilan suatu pembelajaran dapat dilihat dari hasil belajar siswa yang dibuktikan dengan evaluasi belajar yang guru adakan. Itu berarti guru sangat berpengaruh terhadap keberhasilan belajar siswa dan gurulah yang mengerti apakah keberhasilan pembelajaran tercapai. Hasil belajar siswa juga merupakan prestasi belajar siswa, karena prestasi siswa yang diperoleh merupakan bukti dari hasil belajar siswa.

Menurut hasil wawancara dan observasi yang dilakukan peniliti, sekolah mempunyai ruang kelas tersendiri untuk mata pelajaran seni musik, yaitu lab musik yang sudah dilengkapi dengan sarana penunjang pembelajaran seni musik, diataranya lab musik dan ruang karawitan yang sudah dilengkapi dengan alat kedap suara yang dipasang guna tidak mengganggu aktifitas di ruang lain, lab musik mempunyai penerangan lampu yang maksimal, lab musik juga dilengkapi dengan $\mathrm{AC}$ yang membuat nyaman dalam pembelajaran, alatalat musik yang tersedia yaitu keyboard berjumlah dua unit, drum set, gitar elektrik maupun string, bass elektrik, gamelan diantaranya saron dan demung, dan alat-alat musik lain yang disimpan di tempat khusus yaitu biola, pianika, rekorder, bass rekorder, hingga satu set alat musik rebana yang digunakan untuk mengisi acara-acara khusus dalam maupun luar sekolah. Lab musik dilengkapi dengan audio yang cukup baik. Selain lab musik terdapat ruang yang khusus untuk ruang karawitan yang dilengkapi dengan alat musik gamelan lengkap. Menurut hasil wawancara dengan guru seni musik yaitu Suharjan yang menyatakan bahwa ruang kelas seni musik nyaman untuk proses pembelajaran seni musik, sarana pendukung pembelajaranpun tersedia dengan baik. Hal ini tentu saja sangat berpengaruh terhadap keberhasilan suatu proses pembelajaran, karena semakin baik sarana pendukung maka keberhasilan pembelajaran akan semakin baik pula.

Setelah dilakukan penelitian tentang strategi pembelajaran untuk meningkatkan prestasi belajar siswa di SMP Negeri 13 Pekanbaru, diperoleh data yang relevan dengan permasalahan yang diteliti. Data terdiri atas strategi-strategi yang digunakan oleh guru seni musik dalam meningkatkan prestasi belajar seni musik siswa seperti diuraikan dibawah ini:

\section{Strategi Persiapan Pembelajaran}

Menurut hasil wawancara dengan guru seni musik SMP Negeri 13 Pekanbaru pada tanggal 15 November 2017, kegiatan pendahuluan ini sebagai langkah yang memegang peranan penting. Strategi persiapan pembelajaran dirancang guru sebelum mengadakan pembelajaran di kelas. Berdasarkan hasil wawancara dengan Suharjan, selaku guru seni musik SMP Negeri 13 Pekanbaru, pertama kali ia menyiapkan strategi dengan menyusun sendiri Rancangan Pelaksanaan Pembelajaran (RPP) yang mengacu pada silabus. Menurutnya strategi pembelajaran yang pertama kali harus dipersiapkan adalah menyusun dan mempelajari RPP. Hal tersebut dikarenakan bahwa di dalam RPP telah mancakup seluruh komponen-komponen strategi pembelajaran yang akan digunakan, dan setelah rancangan dibuat guru selanjutnya menerapkannya di dalam kelas pada proses pembelajaran.Komponen-komponen yang tercantum dalam RPP yaitu: alokasi waktu, Standar Kompetensi, Kompetensi Dasar, Tujuan Pembelajaran, materi pembelajaran yang dibutuhkan, metode yang digunakan, kegiatan pembelajaran yang akan dijalankan, sumber belajar, media pembelajaran serta alat atau bahan yang digunakan dan evaluasi belajarnya. Komponen-komponen tersebut merupakan acuan untuk merancang pembelajaran yang akan dilaksanakan. Alokasi waktu merupakan ketentuan durasi berlangsungnya pembelajaran yang sudah ditetapkan dalam kurikulum yaitu 2 X 40 menit. Dalam alokasi yang sudah ditentukan tersebut harus dimanfaatkan guru hingga efektif dan efisien.Kompetensi Dasar (KD) adalah konten atau kompetensi yang terdiri atas sikap, pengetahuan, dan ketrampilan yang bersumber pada kompetensi inti yang harus dikuasai peserta didik, KD yang diambil dari silabus namun materi pembelajaran harus diperhatikan dengan kebutuhan dan kemampuan siswa, menurut Suharjan pembelajaran seni musik tidak boleh membebankan siswa, pembelajaran harus menyenangkan termasuk pada materi pembelajaran harus diperhatikan dengan kemampuan siswa yang tetap harus mengacu kepada kurikulum dan silabus. 
Pada alokasi waktu yang tecantum, guru benar-benar memperhitungkan waktu yang digunakan untuk menyampaikan materi pembelajaran. Didalam RPP harus jelas tertulis alokasi waktu yang digunakan untuk tiap-tiap kegiatan dalam proses pembelajaran sehingga materi pelajaran dapat disajikan guru dengan jelas dan terarah. Pada standar kompetensi dan kompetensi dasar yang guru tuliskan sesuai dengan kurikulum yang terdapat dalam silabus. Materi pembelajaran yang berpedoman dengan silabus tersebut harus benar-benar memperhitungkan kebutuhan dan kemampuan siswa serta memperhatikan sarana atau alat pendukung. RPP sangat membantu guru dan memudahkan guru dalam menyiapkan strategi pembelajaran dengan baik. RPP dibuat guru bebarapa hari sebelum guru melakukan pengajaran di jelas. Alokasi waktu untuk mempelajari satu kompetensi dapat terdiri dari beberapa pertemuan pembelajaran yang tentunya sudah sangat diperhitungkan oleh guru dengan efektif efesien. Setiap pertemuan pembelajaran terbagi menjadi tiga bagian yaitu: kegiatan pendahuluan, kegiatan inti dan diakhiri dengan kegiatan penutup. Setelah RPP sudah benarbenar dipelajari dan dimengerti guru, guru mengecek alat-alat yang akan dibutuhkan dalam proses pembelajaran, seperti mengecek ketersediaan alat musik dan memastikan alat dan bahan yang akan dipergunakan dalam kondisi yang baik agar tidak mengganggu jalannya proses pembelajaran.

Berdasarkan wawarcara dan obervasi yang telah peneliti lakukan, guru menyiapkan materi pembelajaran sendiri, guru mencari lagu yang menarik, mudah untuk siswa pahami baik lagu maupun akordnya, setelah guru mendapatkan lagu yang sudah disesuaikan dengan materi, guru mengaransemen lagu kedalam bentuk ansambel musik campuran maupun kedalam format band ataupun yang lain tergantung kebutuhan pembelajaran. Contoh materi lagu untuk kelas 8 guru menggunakan lagu Soleram yaitu lagu daerah dari Provinsi Riau yang diaransemen oleh guru dalam bentuk ansambel campuran, dan lagu Lancang Kuning daerah dari Provinsi Riau yang juga telah diaransemen sendiri oleh guru. Hal ini sedana dengan pernyataan siswa yang bernama Haziq Bahyamhar dan Muhammad Raqel mereka menyatakan bahwa materi lagu yang diberikan kepada siswa yaitu lagu-lagu yang telah diaransemen sendiri oleh guru seni musik yaitu Marjeni Maisasna, S.Pd.

Hasil observasi pembelajaran pada tanggal 14 Oktober 2017 pada pembelajaran kelas IX.10, di ruang praktek musik SMP Negeri 13 Pekanbaru, sebelum siswa memasuki lab musik, guru mengecek alat-alat musik yang akan dipergunakan, diantaranya keyboard, gitar elektrik dan bass elektrik sambil menunggu siswa memasuki ruang musik. Siswa terlihat terapresiasi untuk mengikuti pembelajaran seni musik, ini dibuktikan dengan siswa yang bersemangat, setiap siswa membawa alat musik yang beragam, berdasarkan wawancara dengan guru, siswa diberi tugas untuk memilih sendiri dalam memainkan alat musik untuk bermain musik secara ansambel campuran, yang dimainkan bersama-sama satu kelas. Alat musik yang digunakan siswa sebagian milik siswa pribadi dan sebagian milik sekolah. Alat musik tersebut yaitu rekorder, pianika, acordean, gitar melodi, gitar bass, dan gendang, hingga drum set yang terdapat dalam alat musik dan beberapa siswa membentuk menjadi kelompok vokal.

Cara-cara yang dilakukan guru mempunyai alasan-alasan tertentu, tujuannya agar standar kompetensi menjadi bisa dipahami dan dicapai tujuannya oleh siswa. Dengan upaya guru seni musik SMP Negeri 13 Pekanbaru merancang pembelajaran dengan matang, menunjukkan bahwa guru menggunakan strategi persiapan pembelajaran dengan baik,karena proses pembelajaran akan berjalan dengan baik apabila dilakukan strategi persiapan pembelajaran dengan baik pila. Senada dengan hasil wawancara dengan guru seni musik SMP Negeri 13 Pekanbaru menyatakan bahwa penyusunan perencanaan pembelajaran merupakan suatu keharusan sebagai pengajar karena didorong oleh kebutuhan agar pelaksanaan pembelajaran terarah sesuai dengan tujuan dan sasaran yang ingin dicapai.

\section{Strategi Pengelolaan Pada Masing-Masing Kelas}

Temuan dilapangan memperlihatkan guru menerapkan proses pengelolaan yang berbeda-beda pada masing-masing kelas. Berdasarkan wawancara yang peneliti lakukan dengan guru seni musik SMP Negeri 13 Pekanbaru yaitu Marjeni Maisasna S.Pd menyatakan bahwa beliau menerapkan pengelolaan yang berbedabeda antara kelas yang satu dengan yang lainya dengan alasan guru harus menyesuaikan karakteristik kelas yang tampak pada perilaku siswa yang berbeda-beda yang diantaranya juga adanya perbedaan latar belakang, 
72 Instructional Development Journal (IDJ), Vol. 1, No. 2, Desember 2018, Hal. 67-80

kondisi dan kemampuan siswa. Meski penerapannya berbeda-beda namun guru tetap konsisten dengan menggunakan RPP sebagai acuan dan pedoman.

Sebagai contoh dari hasil pengamatan peniliti pada tanggal 14 Oktober 2017 di kelas IX.10 dan pada tanggal 17 Oktober 2017 di kelas IX.1 dalam materi yang sama yaitu permainan musik ansambel, guru menerapkan pengelolaan kelas yang berbeda. Pengamatan yang dihasilkan dalam kelas IX.10 siswa terlihat aktif dalam pembelajaran namun dalam permainan musik ansambel mereka telihat masih belum baik, diantara beberapa siswa terlihat masih belum menguasai materi pelajaran, maka dari itu guru mensiasati hal tersebut dengan cara mengelompokan siswa kedalam kelompok-kelompok kecil, kelompok tersebut terdiri dari kelompok vocal, rekorder, gitar baik bass maupun melodi, pianika, bass, drum set, keyboard dan biola. Kelompok tersebut berasal dari pilihan intrumen yang dipilih siswa masing-masing sebelum pembelajaran ansambel musik diadakan.

Seperti yang diungkapkan siswa yang bernama Bunga dan Ardian mengungkapkan bahwa siswa memilih instrumen musik sendiri-sendiri setiap pembelajaran musik dilaksanakan. Dengan demikian dapat disimpulkan bahwa guru tidak membebani siswa dalam setiap pembelajaran, dan terlihat bahwa adanya hubungan timbal balik yang baik antara siswa dengan guru. Setelah kelompok-kelompok tersebut terbentuk, guru memerintahkan mereka belajar bersama dengan kelompok masing-masing sedangkan guru mengamati proses latihan siswa, guru mendekat kepada kelompok-kelompok siswa secara bergantian dengan tujuan mengamati dan membantu proses belajar siswa, dan sesekali siswa mengajukan pertanyaan-pertanyaan seputar materi pelajaran dan sesekali siswa juga meminta bantuan guru dalam memainkan instrument musik tersebut. Peneliti melihat adanya kerjasama yang baik antar siswa dalam kelompok, siswa terlihat saling membantu dalam proses belajar memainkan alat musik. Pada lain kesempatan, peneliti menanyakan kepada guru seni musik SMP Negeri 13 Pekanbaru perihal dengan hasil pengamatan yang peneliti lakukan, guru mengungkapkan bahwa tujuan diadakannya pengelolaan kelas dengan membuat kelompok belajar tersebut bertujuan agar pembelajaran lebih mudah tercapai karena siswa termotivasi dengan melihat siswa lain yang sanggup memainkan intrumen musik tersebut.

Sedangkan pada hasil pengamatan yang peneliti peroleh dari kelas IX.10, siswa terlihat lebih siap dalam pembelajaran dan lebih terlihat menguasai materi pelajaran. Pada permainan musik ansambel kelas IX.1 terlihat lebih berhasil dalam pembelajaran. Namun tidak dipungkiri tetap ada beberapa siswa yang belum bisa menguasai materi pelajaran, namun jumlahnya sedikit dibandingkan dengan jumlah siswa yang telah berhasil menguasai materi pelajaran. Hasil pengamatan peneliti menemukan guru menerapkan cara yang berbeda dengan kelas IX.10. Dari permasalahan yang ada yaitu adanya beberapa siswa yang belum menguasai materi pelajaran guru mengambil langkah dengan cara mendekat langsung kepada siswa-siswa yang dianggap belum menguasai materi. Disamping siswa-siswa lain latihan masing-masing dan beberapa siswa mengelompok untuk saling memberi bantuan, guru mendekat secara khusus kepada siswa yang kesulitan dan dengan sabar dan telaten guru membantu siswa dalam memainkan instrument musik yang telah siswa pilih sendiri. Pengelolaan demikian dilakukan terus menerus oleh guru jika guru benar-benar dibutuhkan siswa secara khusus untuk membantu siswa dalam proses pembelajaran. Pengelolaan kelas lainnya, dapat dilihat pada kebiasaan guru dalam memberi pertanyaan-pertanyaan pada siswa mengenai materi pelajaran pada pertemuan sebelumnya. Pada setiap awal pembelajaran dimuai guru mengajukan pertanyan untuk mengetahui seberapa daya serap siswa terhadap materi yang pernah disampaikan. Selain pertanyaan-pertanyaan guru juga mempunyai kebiasaan untuk meminta siswa memainkan instrumen atau alat musik kepada beberapa siswa, hal ini dilakukan jika materi pelajaran pada pertemuan sebelumnya adalah praktek.

Dari hasil pengamatan pada saat pembelajaran seni musik di SMP Negeri 13 Pekanbaru penulis juga menemukan bahwa guru seni musik dalan pelaksanaan pembelajaran seni musik selalu didasarkan pada Rancangan Pelaksanaan Pembelajaran (RPP). Diantaranya hal ini dapat dilihat dari kegiatan guru pada awal mula pembelajaran, pada bagian inti pembelajaran dan pada akhir pembelajaran yang diterapkan di kelas, sama dengan yang tercantum dalam RPP. Hal ini menunjukan bahwa guru telah konsisten dalam menerapkan strategi pengelolaan pembelajaran di dalam kelas sesuai dengan strategi persiapan sebelumnya. 
Sebagai contoh, berdasarkan pengamatan peneliti pada pembelajaran kelas IX.10, dan IX.1 pada tanggal 26 Oktober 2017 penulis mendapat hasil pengamatan pembelajaran menggunakan strategi berkelompok tampak strategi pada kompetensi menampilkan hasil aransemen lagu mancanegara di Asia. Guna mencapai tujuan kompetensi ini, guru menggunakan strategi berkelompok dengan tahapan seperti berikut: 1) Pada tahap awal pembelajaran, guru menyajikan musik dengan menggunakan media laptop dengan bantuan speaker hingga benarbenar bisa didengar siswa dengan jelas. Guru memperkenalkan materi lagu baru kepada siswa yaitu lagu mancanegara yang berjudul wonderfull tonight. Guru membagi partitur lagu kepada siswa yang sudah diaransemen guru sesuai dengan kebutuhan pembelajaran. Guru memutar lagu berkali-kali, guru mengikuti dengan memainkan bermacam alat musik dengan bergantian diantaranya gitar melodi, gitas bass dan keyboard dengan tujuan memberi gambaran kepada siswa yang kemudian diikuti oleh siswa dengan menyanyikannya; 2) Pada kegiatan inti pembelajaran, guru membagi kelompok siswa berjumlah 5 sampai 6 siswa setiap kelompok. Guru membagi kelompok siswa dengan diundi, dengan tujuan agar dalam pembagian kelompok guru bersikap adil terhadap siswa. Setelah kelompok terbentuk, guru menjelaskan bahwa setiap kelompok merupakan satu kelompok band yang dengan personil 5 sampai 6 siswa. Format band tersebut menggunakan instrument gitar melodi, gitar bass, drum set, keyboard dan vocal. Setelah guru menjelaskan sedemikian, siswa berkelompok dengan anggota kelompok masingmasing bertuan agar setiap kelompok membagi tugas masing-masing anggotanya. Setelah kelompok terbentuk guru memberikan waktu kepada siswa untuk latihan memainkan alat musik dengan bantuan siswa yang lain yang sudah mahir dengan dibantu guru, secara bergantian menggunakan alat musik dari sekolah; dan 3) Pada bagian akhir pembelajaran, guru menanyakan pengalaman siswa dalam belajar, menanyakan kesulitan siswa dalam belajar, mengevaluasi siswa, dan memberi nasehat arahan kepada siswa sampai pada memberi gambaran kegiatan pembelajaran untuk minggu depan.

Strategi berkelompok diterapkan dengan tujuan agar siswa mendapat pengalaman belajar yang dibutuhkan siswa, seperti saling menghargai, saling berbagi, dan saling bertukar pendapat antar siswa, wawasan siswa lebih terbuka karena siswa-siswa dihadapkan pada situasi untuk berbagi pendapat, berbagi keterampilan misalanya tentang cara membaca notasi, cara menyanyikan dan cara memainkan alat musik. Terkait dengan pembelajaran seni musik di SMP Negeri 13 Pekanbaru peran guru dalam pengelolaan kelas selama proses pembelajaran terlihat ketika guru memberikan motivasi kepada siswa baik secara langsung maupun tidak langsung dengan nasehat-nasehat dan himbauan agar semangat siswa tetap terjaga hingga akhir pembelajaran.

\section{Strategi Penggunaan Media Pembelajaran}

Strategi pembelajaran yang harus diterapkan guru dalam proses pembelajaran yang perannya sebagai manager pengajaran juga meliputi bagaimana guru harus menggunakan media atau sarana pembelajaran yang menarik yang tentu saja harus mempermudah proses siswa dalam menangkap informasi dari guru. Agar proses pembelajaran berjalan dengan lancar guru mengatur ketersediaan sarana pendukung sesuai dengan kebutuhan yang akan dimanfaatkan. Pada saat penulis melakukan observasi penelitian, materi pembelajaran seni musik di kelas IX di SMP Negeri 13 Pekanbaru sedang membahas mengenai permainan musik daerah dengan gitar. Pada materi pembelajaran ini guru selain menggnakan metode pembelajaran ceramah, juga menggunakan metode pembelajaran demonstrasi dan praktik. Banyaknya gitar dari sekolah kurang memenuhi di banding dengan jumlah siswa yang banyak, maka guru mensiasati agar siswa yang sanggup mengusakan membawa alat musik gitar sendiri, namun tidak bersifat wajib agar tidak membebankan siswa, sehingga sebagian siswa membawa gitar sendiri, dan bagi siswa yang tidak memegang gitar baik milik sekolah maupun milik pribadi guru memerintahkan siswa mengelompok dengan teman yang lain agar tetap belajar dengan kelompoknya.

Guru harus menciptakan kegiatan belajar yang menyenangkan karena mengingat tidak semua siswa senang dalam permainan musik gitar, karena setiap siswa memiliki kegemaran dalam memainkan alat musik yang lain. Guru tetap berpegang teguh dengan prinsip bahwa dalam pembelajaran musik siswa tidak mengharuskan siswa mahir dalam memainkan alat musik. Di sinilah peranan guru dituntut dapat berperan menciptakan pembelajaran yang kondusif dan menyenangkan terkait dengan isi materi dan penggunanan media pembelajaran dan penggunaan sarana pembelajaran. Strategi penggunaan media pembelajaran juga terlihat dari 
74 Instructional Development Journal (IDJ), Vol. 1, No. 2, Desember 2018, Hal. 67-80

hasil penelitian proses pembelajaran tanggal 26 Oktober 2017 peneliti berhasil menyimpulkan dengan melihat keseluruhan proses pembelajaran pada materi pelajaran yakni permainan musik ansambel. Media yang utama yang guru persiapkan yaitu bahan lagu mancanegara wonderfull tonight yang sudah guru aransemen sendiri dan ditulis dalam bentuk notasi musik kemudian guru membagi materi lagu kepada siswa dalam bentuk hard copy. Kemudian dalam mengenalkan dan memperdengarkan lagu baru guru menggunakan laptop dan speaker. Selanjutnya guru ikut serta memainkan alat musik seiring dengan jalannya lagu tersebut dengan menggunakan alat musik gitar, keyboard, bass dan drum set secara bergantian, yang selanjutnya guru memerintahkan beberapa yang dianggap sudah mampu memainkannya untuk memainkan lagu tersebut. Strategi penggunaan media pembelajaran oleh guru juga terbukti dari hasil pengamatan penulis pada tanggal 26 Oktober 2017 yakni dalam proses evaluasi atau pengambilan nilai ulangan harian pada kelas IX.10, siswa memainkan progresi akord lagu dan diikuti dengan permaianan melodi disertai iringan dari keyboard yang dimainkan oleh guru.

Terkait dengan persiapan guru dalam mempersiapakn alat-alat musik di ruang musik sebelum pembelajaran, guru juga menyiapkan materi yang akan dibahas pada pertemuan tersebut. Dari hasil pengamatan pada saat observasi diketahui bahwa dalam setiap penyampaian materi pelajaran guru tidak menggunakan buku paduan untuk siswa, namun dalam penyampaian pelajaran guru yang menjelaskan dengan sesekali mencatat hal penting di papan tulis yang kemudian dicatat oleh siswa. Selain itu materi lagu yang telah guru siapkan sendiri itu dibagikan kepada siswa masing-masing sesuai dengan kebutuhan siswa. Sebagai guru seni musik SMP Negeri 13 Pekanbaru. Marjeni Maisasna, S.Pd memiliki alasan sendiri mengapa tidak menggunakan buku panduan untuk siswa dikrenakan ini merupakan salah satu motifasi untuk belajar siswa karena siswa menjadi termotifasi untuk mendengarkan, mencatat hal-hal penting dari penjelasan guru, selain itu juga agar ingatan siswa lebih baik dalam hal mengingat materi karena siswa sendirilah yang mencatatnya.

Keberhasilan suatu strategi atau metode pembelajaran pada dasarnya membutuhkan ketersediaan sarana yang memadai. Ketersediaan alat seni musik ketika diperlukan juga menunjukan terdapatnya persipan pembelajaran yang baik pula. Pernyataan guru seni musik pada kesempetan wawancara pada tanggal 26 Oktober 2017 menjelaskan bahwa ketersediaan alat musik di sekolah sangat mendukung pembelajaran karena guru dapat dengan mudah untuk proses pembelajaran dan guru juga dapat dengan langsung mendemonstrasikan cara memainkan alat musik. Hal ini sekaligus memberikan informasi bagaimana dalam penyajian materi pemeblajaran seni musik di SMP Negeri 13 Pekanbaru sarana pendukung dilakukan secara maksimal. Pengggunaan lab musik memang sangat membantu guru dan siswa dapat tanpa banyak menggangu siswa-siswa di kelas lain. Pembelajaran seni musik tidak dapat disampaikan secara teori saja di depan kelas, tetapi harus banyak melakukan praktek. Berdasarkan pernyataan guru seni musik bahwasanya setiap pembelajaran seni musik baik teori maupun praktek tetap dilaksanakan di lab musik karena beliau mempunyai pedoman bahwa dalam pembelajaran teori sekalipun dalam seni musik tetap menghadirkan unsur bunyi karena itu agar efektif dan tidak memnganggu kelas lain, teori juga tetap dilaksanakan di ruang musik. Hal ini juga disampaikan oleh siswa bernama Raphael, Rizal dan Anji bahwa setiap pembelajaran seni musik selalu diadakan di ruang musik, siswapun berpendapat bahwa pembelajan seni musik di ruang musik sangat nyaman.

SMP Negeri 13 Pekanbaru memiliki dua lab musik dengan dilengkapi alat-alat musik yang cukup lengkap yang dapat dipergunakan untuk kegiatan musik, baik dalam kegiatan pembelajaran maupun kegitan latihan musik yang lain di luar jam pelajaran. disamping guru telah menyiapkan bahan ajar untuk menyampaikan materi teori, guru juga memersiapkan alat musik untuk mempraktekkannya. Hal tersebut juga dikemukakan oleh kepala sekolah SMP Negeri 13 Pekanbaru yang berhasil penulis wawancarai pada tanggal 26 November 2017 yaitu pengadaan berbagai fasilitas pandukung di sekolah dimaksudkan agar dimanfaatkan secara maksimal sehingga para siswa lebih menguasai materi pelajaran. Selain lab musik seolah ini juga mempunyai tempat lain untuk dipergunakan belajar seni musik yaitu di dalam aula SMP Negeri 13 Pekanbaru di unit dua. Aula tersebut dipergunakan secara bergantian sesuai dengan kebutuhan kegiatan yang di dalamnya tersedian seperangkat alat musik gamelan jawa lengkap. Alat musik gamelan jawa tersebut dipergunakan untuk ekstrakulikuler musik karawitan dan acara-acara disekolah yang dibutuhkan. 
Jumlah alat musik yang cukup lengkap yang tersedia di sekolah ini namun terkadang tidak memnuhi untuk seluruh siswa, karena itu pemakaiannya harus bergantian, seperti alat musik keyboard yang tersedia tiga unit yang dalam pemaikannya untuk pembelajaran dipergunakan secara bergantian, begitu juga drum set yang tersedia hanya satu set saja, ada juga alat musik biola yang berjumlah ini juga dipergunakan untuk kebutuhan siswa dalam pembelajaran maupun dalam kegiatan musik yang lain. Pengadaan alat musik memang tidak harus lengkap untuk seluruh jenis alat musik, karena tujuan pendidikan seni musik di tingkat SMP bukan dimanfaatkan untuk mengikuti minat setiap siswa. Sekolah hanya memberikan ruang pembinaan bagi siswasiswa yang benar-benar memiliki bakat musik. dalam konteks ini, minat bakat dan kemampuan siswa dapat disalurkan melalui kegiatan ekstrakulikuler atau kegiatan seni musik di luar sekolah.

Cara guru menyediakan sarana pembelajaran dengan melibatkan siswa ini berpengaruh pada siswa yang bersangkutan untuk lebih aktif dalam pembelajaran. Guru mengatur ketersediaan sarana alat musik ini merupakan bagian dari strategi yang terapkan oleh guru, sehingga para siswa lebih siap dlam mengikuti pembelajaran dan lebih aktif. Peran guru dalam menyiapkam pembelajaran menyarankan untuk mengatur sedemikian rupa berbagai suatu daya pendidikan untuk mencapai tujuan pembelajaran. Dalam hal ini strategi pembelajaran diterapkan guru menyangkut bagaimana cara guru memanfaatkan bahan-bahan dan media pembelajaran agar para siswa dapat menguasai bahan pelajaran dalam rangka memperoleh kompetensikompetensi tertertu sehingga menjadi salah satu langkah untuk meningkatkan prestasi siswa dalam seni musik. Strategi penggunaan media pembelajaran yang demikian ini merupakan suatu faktor keberhasilan dalam pembelajaran yang bertujuanuntuk mencapai tujuan dan perolehan prestasi siswa.

\section{Strategi Pendekatan untuk Memotivasi Siswa}

Hasil observasi dan wawancara dengan guru seni musik SMP Negeri 13 Pekanbaru menunjukan motivasi belajar seni musik siswa tergolong tinggi. Para siswa tampak antusias memperhatikan guru dalam pembelajaran seni musik. Hal ini disebabkan pada kegiatan pembelajaran guru melakukan tindakan yang bersifat memotivasi siswa. Berdasarkan wawancara peniliti sebagai seni musik SMP Negeri 13 Pekanbaru pada tanggal 9 November 2017 guru mengungkapkan bahwa minat siswa SMP Negeri 13 Pekanbaru dalam belajar musik sangat tinggi, ini dibuktikan siswa dalam pembelajaran musik dengan semangat dan antusias, selain itu siswa yang mengikuti kegiatan ekstrakulikuler musik sangat banyak dan dibuktikan dengan kejuarankejuaraan siswa dalam bidang musik. Berdasarkan wawancara mendalam dengan Marjeni Maisasna, S.Pd selaku guru seni musik perihal motifasi siswa, beliau mengungkapkan bahwa untuk membangun motifasi dan minat siswa dalam pembelajaran musik tidak lepas dari peran serta pihak sekolah terhadap dalam mendukung pembelajaran musik baik dalam maupun luar kelas. beliau mengungkapkan bahwa tersedianya sarana pendukung pembelajaran musik yang baik sangat berpengaruh terhadap keberhasilan pembelajaran musik selain tu sekolah ikut serta membantu memberikan wadah pengembangan minat dan bakat siswa dibidang musik.

Strategi dalam memotivasi siswa ini diterapkan dalam pembelajaran karena setiap siswa pada dasarnya memiliki karakteristik yang berbeda, khususnya dalam minat dan bakat seni musik. Tidak setiap siswa mempunyai bakat di bidang musik. Karena itu guru selaku berusaha memeahami bakat-bakat yang dimiliki pada setiap siswa. Para siswa yang berbakat serta mempunyai minat dan keinginan untuk mencapai prestasi dibidang sesni musik memiliki tingkat keterlibatan lebih tinggi disbanding dengan siswa lain yang memiliki karakteristik berbeda baik karakteristik dalam belajar teori maupun mempraktekan vocal maupun memainkan alat musik. Hal ini diperkuat dengan pernyataan guru seni musiknya bahwa sekolah memiliki ruang dan kesempatan siswa dalam bidang musik. Berdasarkan observasi dan wawancara penulis dengan guru seni musik SMP Negeri 13 Pekanbaru, penulis menemukan ketersediaan sarana pendukung musik dan kegiatan ekstrakurikuler musik, sekolah mempunyai ruang musik dan ruang karawitan yang dilengkapi dengan alat musik yang cukup lengkap, serta sekolah mempunyai alat musing marching lengkap, hal demikian juga diperkuat dengan penyataan kepala sekolah yaitu bahwa adanya sarana pendukung hingga kegiatan pendukung tersebut merupakan bentuk apresiasi sekolah kepada minat dan bakat siswa, sekolah memberikan 
76 Instructional Development Journal (IDJ), Vol. 1, No. 2, Desember 2018, Hal. 67-80

wadah sedemikian bertujuan agar minat bakat dan kemampuan siswa dapat tersalurkan dan dalam upaya meningkatkan prestasi siswa dalam hal ini yaitu dalam bidang musik.

Adanya fasilatas dan kegiatan pendukung demikian merupakan salah satu bentuk langkah memotifasi siswa untuk belajar musik, karena bentuk motifasi siswa dalam bentuk apapun jika tidak didukung dengan pelaksanaannya maka usaha akan sia-sia. Selain dalam bentuk sarana yang mendukung pembelajaran musik maupun kegiatan pendukung pengalaman musik, peneliti menemukan langkah guru dalam memotifasi siswa di dalam kelas pada saat pembelajaran. Berdasarkan wawancara penulis sebagai guru musik SMP Negeri 13 Pekanbaru pada tanggal 9 November 2017 guru mengungkapkan bahwa langkah memotifasi siswa dalam pembelajaran musik yaitu dengan membuat pembelajaran yang menyenangkan, dan diminati siswa, diataranya dengan pemilihan materi belajar yang baik, serta materi disesuaikan dengan kemampuan siswa.

Keberhasilan guru dalam memotivasi dibuktikan pada siswa yang menyimak setiap penjelasan dari guru, mencatat hal penting dari penjelasan guru, bertanya kepada guru mengenai materi pelajaran yang sedang dibahas, siswa enjoy terlihat senang dalam mengikuti pembelajaran serta keaktifan siswa mempraktekan dengan seksama uraian materi pelajaran dari guru. Berdasarkan pengamatan yang peneliti lakukan, penulis menemukan antusias dan semangat siswa dalam pembelajaran seni musik, ini terlihat dari sebagian besar siswa yang membawa alat musik sendiri dari rumah, beberapa siswa memiliki alat musik sendiri, dan beberapa siswa menggunakan alat musik sekolah. Alat musik yang dimiliki siswa sebagian besar yaitu rekorder dan pianika, selain itu ada beberapa siswa yang mempunyai alat musik biola dan alat musik gitar. Berdasarkan wawancara dengan siswa mengungkapkan bahwa dalam pembelajaran guru bersikap ramah kepada siswa, mereka senang dengan materi pelajarannya, karena jika siswa kesulitan guru tidak kecawa namun akan diajari secara sabar.

Kegiatan pembelajaan merupakan kegiatan yang berproses, guru harus dengan tulus ikhlas dalam bersikap, berbuat, serta mau memahami anak didiknya dengan segala konsekuensinya. Semua kendala yang terjadi dan dapat menjadi penghambat jalannya proses pembelajaran, baik berpangkal dari perilaku peserta didik, harus guru hilangkan, dan bukan membiarkannya. Karena keberhasilan belajar lebh banyak ditentukan oleh guru dalam mengelola kelas. Demikian juga menjadi salah satu bentuk motifasi kepada siswa untuk tetap belajar dengan baik seperti yang dilakukan oleh guru seni musik SMP Negeri 13 Pekanabaru sebagai dari hasil obsevasi penulis saat pembelajaran berlangsung, guru menggunakan pendekatan yang arif dan bijaksana di dalam pembelajaran, sebagai contoh guru menegur siswa yang kurang konsentrasi dalam belajar dengan bahasa yang tidak menyinggung perasaan siswa, guru mendekat langsung kepada siswa dan menasehatinya secara pelan, karena jika siswa lain mendengar kemungkinan besar siswa akan menjadi malu.

Ada dua siswa yang bersama-sama memainkan gitar akustik didepan, yaitu Muhammad Iqbal F dan Muhammad Reyhan, sedangkan permainan drum set oleh siswi kelas IX yaitu Fitria Zahra, kemudian permainan biola oleh, dan permainan kelompok perkusi oleh 8 siswa dengan dipandu oleh guru. Mereka bermain musik dengan disaksikan peresta workshop tanpa ada persiapan sama sekali. Ini menunjukan bahwa siswa terapresiasi setelah melihat langsung permainan musik dari SMM. Penulis berhasil mewawancarai beberapa siswa yaitu Mutiara Yeliza, Nirmala Widya Putrid dan Ovalia Hermansyah.M, mereka mengungkapkan bahwa kegiatan seperti ini buka saja membuat refresing namun juga memberi semangat baru dan pengalaman yang baru juga.

Prestasi yang diperoleh siswa-siswa di SMP Negeri 13 Pekanbaru juga mendeskripsikan bahwa para siswa semakin baik keterampilannya dalam bidang musik. Meskipun hal ini tidak diikuti oleh semua siswa namun mereka yang memang sudah mempunyai bakat dalam bidang music Hal ini tidak mengesampingkan guru dalam upaya membina bakat seseorang dalam bidang musik, karena tanpa adanya pembinaan maka bakat seseorang dalam bidang apapun tidak dapat berkembang. Pembinaan dalam bidang seni musik tentu membutuhkan sosok yang memiliki otoritas keilmuan dan keahlian dalam bidang musik. Dalam upaya menyukseskan kegiatan kegiatan yang berkaitan dengan musik dan tentu saja dengan tujuan meningkatkan keberhasilan sekolah dalam perolehan prestasi-prestasi siswa. Dalam pelaksanaan latiahan musik atau ektrakulikuler musik bukan hanya melibatkan guru seni musik yaitu Ibu Marjeni Maisasna, S.Pd dan guru seni music lainnya 
bernama ibu Husni Sasmita, S.Pd yang juga mempunyai keahlian dalam bidang musik, sekolah juga menghadirkan pelatih-pelatih yang dianggap membantu untuk menyukseskan kegiatan tersebut..

Kemampuan guru seni musik yaitu Marjeni Maisasna, S.Pd mengenai pengetahuan dan keterampilan musik terbukti karena beliau telah mendukung para siswanya untuk mencapai prestasi di bidang musik, sebab pembelajaran seni musik apabila diberikan terhadap siswa-siswa yang mempunyai bakat musik sekalipun, tetap membutuhkan metodemetode tertentu yang menunjukan kesabaran, ketekunan, dan kebijaksanaan dalam penyampaian materi dan membimbing mereka dalam praktek. Hal inilah yang menjadikan guru seni musik SMP Negeri 13 Pekanbaru mnerapkan strategi pembelajaran yang tepat dan menerapkan strategi yang variatif dalam satu pertemuan pembelajaran, bukan hanya dalam hal metode, guru juga menggunakan strategi motifasi belajar kepada siswa, karena motivasi sangat perpengaruh terhadap perkembangan peserta didik.

\section{Strategi Evaluasi dan Pengambilan Nilai}

Guru dalam melakukan evaluasi tentu dengan tujuan, yaitu untuk mengetahui seberapa jauh kemampuan siswa dalam belajar, untuk mengetahui kekurangan dan kelemahan siswa, dan juga untuk mengukur kesuksesan guru dalam mengajar. Pengambilan nilai hasil belajar disamping memperlihatkan kemampuan siswa dalam menjawab pertanyaan guru pada saat pembelajaran berlangsung juga dilakukan dengan mengadakan ulangan harian dan praktek. Setiap kali akan diadakan penilaian guru terlebih dulu memberikan informasi kepada siswa pada pertemuan sebelumnya namun tanpa menyebutkan waktu tepatnya, tujuannya agar siswa termotifasi untuk terus belajar. Sebagai bagian dari pelaksanaan strategi evaluasi pembelajaran guru juga berperan melakukan evaluasi pengajaran. Dalam kegiatan ini, guru seni musik SMP Negeri 13 Pekanbaru memberikan penilaian dalam teori dan praktek. Setelah satu kali putaran permainan guru mengevaluasi secara keseluruhan, kemudian diulang kembali satu putaran permainan. Hal demikian mempunyai maksud agar mengingat kembali materi pelajaran yang akan dinilai. Selain itu, guru juga mempunyai alasan agar membuat siswa percaya diri dan tidak gerogi. Setelah itu, guru menjelaskan tata cara penilaian, penilaiannya yaitu tiga siswa memainkan bersama di dalam lab musik, dan siswa yang lain menunggu dan latihan diluar lab musik, penilaian diurut sesuai dengan absensi siswa.

Berdasarkan pengamatan peneliti pada saat penilaian di dalam ruang musik, sebelumnya guru mengecek absensi siswa, guru menanyakan kesiapan siswa dengan senyum ramah. Setelah semua siap, barulah penilaian dimulai, lagu dimainkan satu kali putaran, setelah itu guru dengan langsung mengevaluasi perminan musik siswa, dan mengarahkan. Jika diperlukan guru mengungali satu kali perbaikan kepada siswa. Kemudian seterusnya hingga selesai. Setelah semua siswa guru mengevaluasi secara keseluruhan. Guru mengevaluasi sejauh mana pengejaran musik kepada siswa telah berhasil.Setiap kali penilaian selesai guru mengungkapkan bahwa pada dasarnya semua siswa mendapat nilai yang baik, namun akan lebih baik lagi jika seluruh siswa berhasil dalam mencapai target penialain maka dari itu guru memberikan satu kali kesempatan kepada siswa yang dianggap memerlukan tes remedial. Remedial dilaksanakan pada pertemuan berikutnya. Sebelum remedial dilaksanakan terlebih dulu guru membimbing kembali siswa yang masih kesulitan dalam materi pelajaran.

Dari hasil observasi peneliti dengan dibuktikan dengan contoh bentuk evaluasi pembelajaran dengan jalan memberi pertanyaanpertanyaan lisan setiap kali dalam awal pembelajaran, diadakannya ulangan harian setiap kali penyelesaian suatu Kompetensi Dasar, dan evaluasi setiap kali penyelesaian penilaian, diadakannya tes remiadial, dan tes universal yaitu ujian tengah semester dan ujian semester. Ini membuktikan bahwa guru menggunakan strategi evaluasi dan pengambilan nilai. Strategi evaluasi dan pengambilan nilai ini merupakan langkah guru dalam mengetahui seberapa jauh kemampuan siswa dalam belajar, untuk mengetahui kekurangan dan kelemahan siswa, dan juga untuk mengukur kesuksesan guru dalam mengajar, dengan demikian guru akan mengevaluasi dirinya dalam hal memberi informasi kepada siswa, kemudian guru akan memperbaiki strategi mengajarnya demi keberhasilan mencapai tujuan pembelajaran dan pencapaian prestasi belajar siswa. 
78 Instructional Development Journal (IDJ), Vol. 1, No. 2, Desember 2018, Hal. 67-80

\section{Strategi Pengembangan Pengalaman Belajar Seni Musik Siswa}

Strategi yang terakhir dilakukan oleh guru seni musik SMP Negeri 13 Pekanbaru yaitu Marjeni Maisasna, S.Pd dalam meningkatkan prestasi belajar seni musik siswa yaitu strategi pengembangan pengalaman belajar seni musik siswa. Strategi ini diupayakan oleh guru setelah proses pembelajaran berjalan dan setelah mengevaluasi hasil belajar siswa. Strategi ini tentu saja merupakan langkah untuk pencapaian keberhasilan tujuan belajar siswa dan peningkatan prestasi belajar siswa. Seperti yang telah diungkapkan guru seni musik SMP Negeri 13 Pekanbaru, beliau mengungkapkan bahwa pengembangan pengalaman belajar sangat penting dilakukan oleh guru dalam pembelajaran, karena dalam memperoleh tujuan pembelajaran yang dicapai atau pencapaian kompetensi diperlukan sejumlah aktifitas yang dilakukan siswa yang dinamakan dengan pengalaman belajar.

Dalam usaha guru seni musik yaitu Suharjan dalam meningkatkan prestasi belajar seni music siswa diperlukan pertimbangan-pertimbangan dalam merancang pengalaman belajar seni musik siswa yaitu diantaranya harus sesuai dengan tujuan dan kompetensi yang akan dicapai, pengalaman harus disesuaikan dengan karakteristik siswa, disesuaikan dengan kondisi atau lingkungan belajar, metode pengajaran yang variatif. Proses pembelajaran adalah proses yang dapat mengembangkan seluruh potensi siswa. Seluruh potensi itu hanya mungkin dapat berkembang manakala siswa tersebut terbebas dari rasa takut, dan menegangkan. Oleh karena itu, Suharjan menyatakan bahwa dalam proses pembelajaran perlu diupayakan agar pengalaman belajar merupakan proses yang menyenangkan. Menyenangkan berarti membuat nyaman siswa maupun guru, ini diupayakan dengan mengkondisikan lingkungan belajar yang nyaman baik dari segi lingkungan belajar yang rapi, bersih, dan indah. Guru mengungkapkan bahwa dalam proses pembelajaran interaksi dengan siswa harus diupayan sehangat mungkin, agar tercipta keharmonisan dalam belajar.

Berdasarkan pengamatan penulis selama proses penelitian, lingkungan belajar seni musik di ruang musik SMP Negeri 13 Pekanbaru sangat memungkinkan untuk membuat kenyamanan baik siswa maupun guru. Ruang musik yang rapih, bersih, alat musik tertata dengan baik, cahaya yang cukup, ruang terhindar dari debu dan bau, pendingin ruangan yang berfungsi baik, dan alat musik yang dalam kondisi siap dipergunakan siswa ini menunjukan bahwa guru benar-benar membuat lingkungan belajar yang nyaman sebagai upaya memotifasi siswa dalam belajar. Sesekali peniliti penjumpai guru untuk merapikan dan membersihkan sendiri lab musik serta alat-alat musiknya, dan mengecek kondisi alat musik.

Temuan lain yang peniliti dapatkan yaitu adanya interaksi yang baik antara guru dengan siswa maupun siswa dengan siswa lainnya, ini terlihat dengan kebiasaan guru yang sesekali bercanda dengan siswa, tidak nampak ketegangan siswa dalam proses pembelajaran, seperti yang dingkapkan oleh beberapa siswa yaitu, Anjun, Bunga, Ardian, Raphael, dan Joya, mereka mengungkapkan bahwa bapak Suharjan dalam proses pembelajaran itu santai dan menyenangkan, tidak membuat beban yang menegangkan kepada siswa. Upaya lain yang guru lakukan yaitu merumuskan tujuan tidak semata-mata ditentukan oleh guru, akan tetapi siswapun terlibat dalam menentukan dan merumuskannya, seperti yang ditemukan peneliti sepanjang proses penelitian, dalam proses latihan musik ansambel, ada beberapa siswa yang berinisiatif untuk memainkan biola, dan hal tersebut disampaikan ke guru agar meminta guru untuk mengaransir lagu,dalam pembagian kelompok guru dan siswa mencari langkah terbaik dalam menentukan kelompok. Ini menunjukan adanya interaksi yang baik antara siswa dan guru.

Temuan lain yang peniliti temukan yaitu guru yang ssekali memberi bantuan dan pelayanan kepada siswa yang memerlukannya, terutama bagi siswa yang mengalami kesulitan dalam belajar, hal ini mendorong siswa untuk lebih aktif dalam belajar, juga sebagai slah satu memberian motivasi belajar kepada siswa. Sebagai langkah memberi pengalaman belajar guru juga menggunakan bantuan media dalam pelaksanaannya. Sebagai contoh berdasarkan hasil pengamatan peniliti, guru selalu menggunakan alat bantu dalam pembelajaran, diantaranya, guru dalam mendemonstrasikan permainan musik, guru memberi contoh langsung dengan memainkannya, penggunaan laptop, DVD, proyektor dan lain-lain. Pengalaman langsung merupakan pengalaman yang diperoleh siswa sebagai hasil dari aktivitas sendiri, siswa mengalami dan merasakan sendiri segala sesuatu dalam proses pembelajaran, sebagai contoh, siswa memainkan alat musik sendiri dengan bantuan 
bimbingan dari guru, baik merirukan permainan dari guru atau dengan membaca partitur sendiri. Pengalaman melalui melalui pertunjukan hasil karya baik secara individu maupun kelompok. Pengalaman belajar yang peniliti temukan yang bertujuan untuk meningkatkan pengalaman belajar seni musik siswa juga dibuktikan dengan adanya kerjasama antara sekolah-sekolah seni musik lainnya. Pengembangan semacam itu merupakan usaha dari sekolah, usaha yang lain yaitu dengan adanya kegiatan diluar sekolah yaiti kegiatan ektrakurikuler musik yang banyak terselenggara di sekolah. Diantaranya Marcing Band, ektra karawitam, Vokal, band dan instrument musik lainnya, yang dibina oleh guru seni musik sendiri dengan dibantu oleh guru SMP Negeri 13 Pekanbaru yang mempunyai keterampilan dalam musik dan dengan mengadakan guru khusus dari luar sekolah agar pembelajaran lebih baik untuk mencapai prestasi belajar seni musik siswa.

\section{SIMPULAN DAN SARAN}

\section{Simpulan}

Berdasarkan hasil penelitian yang telah diperoleh tentang strategi pembelajaran seni musik untuk meningkatkan prestasi belajar siswa di SMP Negeri 13 Pekanbaru, maka dapat ditarik beberapa kesimpulan seperti berikut: 1) Strategi persiapan pembelajaran. Langkah utama yang ditunjukkan guru dengan pembuatan RPP yang berorientasi kepada kurikulum dan silabus yang digunakan. RPP mencantumkan strategi dan metode pembelajaran yang diterapkan; 2) Strategi pengelolaan pada masing-masing kelas. Guru mengajar dengan metode yang berbeda-beda pada setiap kelas karena setiap kelas memiliki karakter yang berbeda-beda;3) Strategi penggunaan media pembelajaran. Guru mengarah pada persiapan dan memanfaatkan media dan alat belajar yang sesuai dengan materi dan sarana yang tersedia di lab musik sekolah; 4) Strategi pendekatan untuk memotivasi siswa. Untuk memotivasi siswa, guru melakukan pendekatan personal, kelompok dan pendekatan berfasiari. Strategi pendekatan motivasi oleh guru didukung peran serta sekolah dengan menyediakan sarana pendukung pembelajaran yang baik; 5) Strategi evaluasi dan pengambilan nilai. Pada strategi ini guru mengadakan pengambilan nilai tidak hanya pada UTS dan UAS, namun dengan mengadakan ulangan harian setelah penyelesaian Kompetensi Dasar. Guru juga melakukan penilaian setiap saat pada proses pembelajaran berlangsung dengan melihat respon siswa, melihat jawaban pertanyaan lisan dari guru. Hasil evaluasi akan ditindaklanjuti oleh guru sebagai tahap penyempunaan pembelajaran; dan 6) Strategi pengembangan pengalaman belajar seni musik siswa. Pada strategi ini guru melakukan pengembangan aktifitas belajar siswa, dengan memperbanyak aktifitas belajar praktek musik dibandingkan dengan belajar teori musik, namun dengan tidak mengesampingkan teori yang tetap hadir sepanjang berjalannya pembelajaran. Selain itu juga dengan banyaknya aktifitas atau kegiatan pendukung pencapaian prestasi seni musik siswa di sekolah.

\section{Saran}

Berdasakan temuan pada hasil penelitian ini, maka diajukan saransaran untuk strategi pembelajaran yang baik yaitu: 1) Bagi para guru dalam bidang musik dapat menerapkan strategi yang dilakukan oleh guru seni musik SMP Negeri 13 Pekanbaru; dan 2) Bagi para peneliti lain yang meneliti di sekolah yang sama, maka dapat disarankanuntuk meneliti kegiatan ekstrakulikuler seni musik, karena hal tersebut belum dilakukan oleh peneliti dalam penelitian ini disebabkan keterbatasan ruang lingkup penelitian yang dibahas dan keterbatasan waktu penelitian.

\section{DAFTAR RUJUKAN}

Anwar, Khairil. 2013. Kurikulum 2013. Jakarta: Kementrian Pendidikan dan Kebudayaan.

Bahri, Syaiful dan Aswan. 2006. Strategi Belajar-Mengajar. Jakarta: PT. Rineka Cipta

Creswell, John W. 2010. Reseach Design: Pendekatan Kualitatif, Kuantitatif, dan Mixed. Yogyakarta: Pustaka Pelajar.

Hamalik. 2005. Kurikulum dan Pembelajaran. Jakarta: Bumi Aksara. 
80 Instructional Development Journal (IDJ), Vol. 1, No. 2, Desember 2018, Hal. 67-80

Hamzah, Nurdin. 2012, Belajar dengan Pendekatan PAILKEM. Jakarta: PT. Bumi Aksara.

Jamalus. 1991. Pendidikan Seni Musik. Jakarta: Depdikbud

Miles, Mathew B dan Huberman, A. Michael. 1992. Analisis Data Kualitatif. Jakarta: UI Press.

Moleong, Lexy. 2006. Metode Penelitian Kualitatif. Bandung: PT. Remaja Rosdakarya.

Muhibbin, Syah. 2003. Psikologi Pendidikan dan Pendekatan Baru. Bandung: PT. Remaja Rosdakarya.

Mulyasa. 2006. Menjadi Guru Professional: Menciptakan Pembelajaran Kreatif dan Menyenangkan. Bandung: Remaja Rosdakarya.

Notodiputro dan Khairil Anwar. 2012. Kompetensi Dasar untuk Sekolah Menengah Pertama/Madrasah Tsanawiah sebagai Salah Satu Perangkat Kelengkapan Dokumen Kurikulum 2013. Jakarta: Kemendikbud.

Osborn, David dan Peter Plastrik. 2000. Memangkas Birokrasi: Lima strategi Menuju Pemerintahan Wirausaha. Cetakan ke-1. Jakarta: Penerbit PPM

Pasaribu H L, Simandjuntak. 1983. Metode Belajar dan Kesulitan Belajar. Bandung: Tarsito.

Rachmad Tono dan Milyartini Rita. 2004. Kriteria dan Karakteristik Pendidikan Seni Musik. Bandung: Universitas Pendidikan Indonesia

Sanjaya, Wina. 2006. Strategi Pembelajaran Berorientasi Standar Proses Pendidikan. Jakarta: Kencana Prenada Media.

Sanjaya,Wina.2008.Perencanaan dan Desain Sistem Pembelajaran. Jakarta: Kencana Prenada Media Group.

Sharon, Deborah dan Russel. 2011. Instructional Tecnology And Media For Learning: Teknologi Pembelajaran dan Media untuk Belajar. Edisi ke-9. Penerbit Kencana Prenada Media Grup

Siagian, SP.1988. Administrasi Pembangunan, Konsep, Dimensi, Strategi. Jakarta: CV Haji Masagung.

Sudjana Nana. 2005. Dasar-Dasar Proses Belajar Mengajar. Bandung: Sinar Baru Algensindo.

Sugiyono. 1998. Metode Penelitian Administrasi. Bandung: Penerbit Alfabeta.

Sugiyono. 2010. Metode Penelitian Pendidikan Pendekatan Kuantitatif, Kualitatif dan R\&D. Bandung: Alfabeta.

Surya Mohamad. 2004. Psikologi Pembelajaran dan Pengajaran. Bandung: Pustaka Bani Quraisy

Suryabrata, Sumadi. 2002. Psikologi Pendidikan. Jakarta: PT. Raja Grafindo Persada.

Sutupo. 1988. Pengantar Penelitian Kualitatif : Dasar-dasar Teorotis dan Praktis. Surakarta: Universitas Negri Sebelas Maret.

Wena, Made. 2010. Strategi pembelajaran inovatif kontemporer.Jakarta Timur: Bumi Aksara.

Yayah dan Atiqa. 2004. Pendidikan Apresiasi Musik. Surakarta: Penerbit Pusat Studi Budaya dan Perubahan Sosial Universitas Muhammadiyah 